\title{
Analysis of the static and dynamic properties of wear-resistant Hardox 600 steel in the context of its application in working elements
}

\author{
Ł. Konat, R. Jasiński, B. Białobrzeska*, Ł. Szczepański \\ Faculty of Mechanical Engineering, Wroclaw University of Science and Technology, \\ Wybrzeże Wyspiańskiego 27, 50-370 Wroclaw, Poland
}

\begin{abstract}
The article discusses the static and dynamic properties of high-strength, boron-containing Hardox 600 steel that is resistant to abrasive wear, both in its delivery state and after normalization. Since the available published material in the literature does not have any real mechanical indicators of the abovementioned steel, a static tension test was carried out at an ambient temperature. The steel's tensile strength, yield strength, Young's modulus, elongation and reduction of area were determined from the test. The Charpy impact test at temperatures of $-40{ }^{\circ} \mathrm{C},-20{ }^{\circ} \mathrm{C}, 0{ }^{\circ} \mathrm{C}$, and $+20{ }^{\circ} \mathrm{C}$ and fractographic analysis were performed to determine the transition temperature of ductility to brittleness. In dynamic load conditions, the assigned values of impact energy do not always truly determine the material behavior. Thus, the aim of the fractography was to provide precision when determining the behavior. A significant difference in the impact energy of the tested steel with respect to its heat treatment and ductile-brittle transition temperature was observed and determined based on the impact test result, as well as the nature of the fracture. On the basis of the determined structural and strength characteristics, an analysis of the possibility of application of Hardox 600 steel on selected elements of working machines was performed.
\end{abstract}

Keywords: martensitic boron steel, steel resistant to abrasive wear, mechanical properties, structures, ductile to brittle transition temperature, fractographic analysis

\section{Highlights}

- The static and dynamic properties of the high-strength Hardox 600 steel were determined.

- The conducted tests confirmed that Hardox 600 steel has very high strength indicators.

- Normalization causes a significant degradation of the mechanical properties of the analyzed steel.

\section{Introduction}

The problems that arise due to wear of machine elements, which are detrimental to their durability and reliability, adversely affect the entire production process; these are currently encountered in almost all industries, such as mining, construction,

*E-mail: beata.bialobrzeska@pwr.edu.pl or agriculture [1]. The causative factors that determine the rate at which the wear of machine elements takes place serve, therefore, as the main sources of influence that determine the overall production costs. As a result of the impact of high dynamic loads and the influence of the environment, the greatest threats of wear of machine elements are noted primarily in the mineral resource extraction industry. As a result of the difficult working conditions of these elements, they are frequently replaced, and each machine downtime involves both material costs and fixed costs that are related to the maintenance of the infrastructure. In the case of basic machinery in opencast mining, which is mainly related to the extraction of lignite, these costs are very high. As a result of very large dimensions, weight, and atypical (unitary) construction solutions, the construction process of basic machines in opencast mining requires special design skills, proficiency in computational methods, and the use of the latest solutions in the field of 
system reliability, selection of materials, drives, control, software, and diagnostics; it also requires the establishment of several decades of service life of these facilities in a very demanding environment [2]. Machines with lower processing capacity are used in the exploitation of natural aggregates, i.e., sand and gravel, industrial sands, refractory and ceramic clays, and various aggregates located under the water surface. In terms of construction, as in the rock mining of crushed aggregates, the discussed applications mainly use single-bucket hydraulic backhoe excavators and - less often used - overhanging excavators [3]. The environmental factors causing the wear of excavators and stackers are determined by nature, which means that they cannot be practically regulated. Therefore, activities aimed at optimizing these elements must be focused on the improvement of design and material solutions $[4,5]$. Appropriate, broadly understood process of materials' selection is extremely important in the life cycle of each machine, and the wear of elements and assemblies for material reasons is one of the main causative agents that contribute to the degradation process. For example, in lignite excavators, as many as eleven construction units that are subject to such material degradation have been selected. These are: buckets (blades, ears, sheathing), bucket teeth, rotation mechanism (road wheels, rails), chassis construction (drive unit set, road wheels), crawler chain (track links, crawler treads), chutes, hoppers, transfer stations, body construction (bucket wheel jib, central node), plain bearings, sleeves, worm drives, drive of the mining system and toothed wheel rims, lowering mechanism, and drums of chain conveyors [6-8]. These elements are subject to natural or emergency wear, which can be regulated by the selection of materials and the technologies that aim to bring about their strengthening. Among the abovementioned structural units, seven units, which are part of a system for transporting excavated material, are subject to wear due to the abrasive impact of the processed raw materials. This process takes place at different times for individual teams, and may last from several hours to several dozen years. For example, from the material considerations that apply to the bucket assembly, it can be surmised that the quick-wear elements may include the bucket teeth and lining plates on chutes of bucket wheels. Under difficult operating conditions (soils of the 4th and 5th class of workability), the working time of the bucket teeth is only $0.5-26 \mathrm{~h}$. However, in the case of lining plates, the working time is about $300 \mathrm{~h}$ under extremely difficult conditions [9].

Currently, the steel industry meets the demands of machine constructors, offering newer and better materials in terms of strength parameters. One of the groups of materials, the use of which, according to the opinion of the authors of this study, would reduce the energy consumption of the construction, while increasing its durability, are low-alloy, martensitic steels with boron; these steels are characterized by increased resistance to abrasion [1012]. The common property of the majority of commercially available wear-resistant steels, in addition to the high abrasion-wear resistance claimed by the manufacturers, is their high strength. Their ductility and impact strength (especially at lower temperatures) are also maintained at a sufficient level. The abovementioned properties are obtained through a special thermomechanical rolling, their rigorously selected chemical composition (depending on the thickness of the steel plate), the very low content of unfavorable additives (especially sulfur), and their boron micro-addition (usually $0.002-0.005 \%$ by mass).

Considering the commercial information that is available in relation to materials such as Hardox and Boron steel [13-16] and many other steels, it can be generally surmised that a significant majority of commercially available wear-resistant steels can be characterized by an ultimate tensile strength exceeding 1,500 MPa. In many cases (e.g., Hardox 600 steel, Hardox Extreme, XAR 600, and others), the threshold of static strength equal to 2,000 MPa is also exceeded. The above observation is highly significant due to the fact that the discussed group of materials contain carbon up to $0.50 \%$ by mass; this fact is of key importance in the context of applying welding techniques. Literature on the weldability of high-strength, low-alloy, abrasion-resistant steel is scarce [17-22]. However, when compared with weldability, there is slightly 
more reference in the literature about research into the structural properties and (occasionally) strength of this material group. The results of tribological [23-29] tests are also promising, and further, the advantage of Hardox 400 and Hardox 500 steels in the delivered condition was demonstrated over the previously used wear-resistant materials, such as $37 \mathrm{MnSi} 5, \mathrm{P} 355 \mathrm{~N}$, and $\mathrm{P} 355 \mathrm{~N}$ steels with applied padding weld from the $\mathrm{Fe}-\mathrm{Cr}-\mathrm{C}$ system and high-chromium white cast iron, in the field tests under real-operating conditions of brown coal excavators. However, in none of the articles known to the authors of this study were the mechanical properties (provided by the manufacturers) of abrasionwear resistant steels with a declared tensile strength exceeding 2,000 MPa subjected to scientific assessment. This is especially the case with regard to susceptibility to brittle fracture at low temperatures. Another argument that emphasizes the importance of the discussed problem is the lack of any scientific data regarding the behavior of these materials under dynamic loading conditions, which are characterized by, for example, the value of impact energy in the form of the ductile-brittle transition curve, or the results of fractographic analysis. It was only in a few cases that the technical specifications of the presented steels contained vague information concerning both the values of impact energy at an individual (usually low) temperature and general assurances regarding satisfactory impact strength in various types of applications. Consequently, the authors of this study are of the opinion that the results of their research into selected structural steel characterized by a high strength index - such as Hardox 600 - complement the current state of knowledge in both the scientific and practical aspect of structural steel being applied in a particular industry sector. As Hardox 600 belongs to a group of steels that is generally classified as high-strength, low-alloy, and abrasion-wear resistant, the description of its production and forming, as well as any advertising information, has been excluded. The general properties connected with this material group (including other types of Hardox steel) have been the subject of the study [30-41]. In this study, focus is placed on the basic structural and strength indices of Hardox 600, which involves the longitudinal and transverse orientation of thermomechanical rolling of a steel plate and a temperature range of $-40{ }^{\circ} \mathrm{C}$ to $+20{ }^{\circ} \mathrm{C}$, under which impact-strength tests are typically performed. This enables us to determine the ductile-brittle transition curve. Taking into account the possibility of using welding techniques to join tested steel plates, which involves structural and strength alterations in the steel, the discussed set of tests was applied to tempered steel (as in the delivery state), as well as to steel after normalization.

\section{Materials and methodology}

A sheet of Hardox 600 steel plate was used for the structural and strength tests. The steel plate, delivered straight from the plant, measured $1,000 \mathrm{~mm} \times 700 \mathrm{~mm}$ and was $12 \mathrm{~mm}$ thick. Table 1 demonstrates selected chemical and mechanical properties of Hardox 600 steel, which are based on information from the manufacturer [13].

The specimens for carrying out specific test procedures were cut out from the steel plate using a high-energy water-jet and electro discharge machining (EDM). After cutting, a batch of specimens was normalized in laboratory conditions,. It is worth to take note of the fact that the nomenclature of "normalization" used in the manuscript has a technological meaning, which is the use of open air cooling after austenitization irrespective of the actual structural changes it may cause. However, taking into account the structural changes of Hardox 600 steel subjected to this heat treatment, this terminology may be controversial. The heat treatment was performed in the gas-tight furnace FCF 12SHM/R made by Czylok Company, and in the inert atmosphere of $99.95 \%$ argon. Normalizing included austenitization at $850{ }^{\circ} \mathrm{C}$ over $60 \mathrm{~min}$ and cooling in open air. The heat treatment parameters were selected based on experimental data and CCT and TTT graphs (Figure 1), which were drawn up for the purpose of the study. They were obtained via computer simulation using JMatPro software. To maintain the optimal cooling rate, the heat treatment was carried out on bigger steel plate fragments, out of which suitable specimens were taken for tests. To account for more intense cooling on 
Table 1. Chemical composition and selected mechanical properties of Hardox 600 steel claimed by the manufacturer (SSAB; Stal-Hurt; SSAB).

\begin{tabular}{|c|c|c|c|c|c|c|c|c|c|c|c|c|c|c|}
\hline $\begin{array}{c}\mathrm{C} \\
\text { Selec }\end{array}$ & $\begin{array}{r}\mathrm{Si} \\
\mathrm{ed} \mathrm{ch}\end{array}$ & $\begin{array}{l}\text { Mn } \\
\text { mical }\end{array}$ & $\begin{array}{c}\text { P } \\
\text { elemen }\end{array}$ & $\begin{array}{c}\text { S } \\
{[\text { maxin }}\end{array}$ & $\begin{array}{c}\mathrm{Cr} \\
\text { num } \text { \% }\end{array}$ & $\begin{array}{l}\text { Ni } \\
\text { by n }\end{array}$ & $\begin{array}{c}\text { Mo } \\
\text { lass] }\end{array}$ & B & $\begin{array}{c}\mathbf{R}_{\mathrm{p} 0.2} \\
{[\mathbf{M P a}]}\end{array}$ & $\mathbf{R}_{\mathrm{m}}$ & $\begin{array}{l}A_{5} \\
{[\%]}\end{array}$ & $\begin{array}{c}\mathbf{K C V}-40 \\
{\left[\mathbf{J} / \mathbf{c m}^{2}\right]}\end{array}$ & $\underset{[\mathrm{mm}]}{\text { HBW }}$ & \# \\
\hline 0.40 & 0.50 & 1.0 & 0.015 & 0.010 & 1.20 & 1.50 & 0.60 & - & NA & NA & NA & NA & $570-640$ & $3.0-5.0$ \\
\hline 0.47 & 0.70 & 1.50 & 0.015 & 0.010 & 1.20 & 2.50 & 0.70 & 0.005 & Min. 1,650 & Min. 2,000 & Min. 7 & Min. 25 & $\begin{array}{l}570-640 \\
550-640\end{array}$ & $\begin{array}{c}6.0-51.0 \\
51.1-65.0\end{array}$ \\
\hline
\end{tabular}

$\mathrm{R}_{\mathrm{p} 0.2}$ - yield strength; $\mathrm{R}_{\mathrm{m}}$-ultimate tensile strength; $\mathrm{A}_{5}$-percentage elongation after fracture for proportional specimens with the original gauge length $\mathrm{L}_{0}$ equal to five times the cross-sectional area; $\mathrm{KCV}_{-40}$ - Charpy V-notch toughness at $-40{ }^{\circ} \mathrm{C}$; HBW-Brinell hardness; \#-steel plate thickness; NA—information not available.

the edges, an adequate margin was maintained. In the last stage, all the specimens were subjected to grinding and polishing to ensure dimensional tolerance and roughness.

Chemical composition analyses were carried out spectrally using a glow discharge spectrometer Leco GDS-500A. The following parameters, enabling ionization of a neutral gas, were applied during the analysis: $\mathrm{U}=1,250 \mathrm{~V}, \mathrm{I}=45 \mathrm{~mA}, 99.999 \%$ argon. The obtained result was the arithmetic mean of at least 5 measurements.

The observation of the microstructure was performed using a Nikon Eclipse MA200 light microscope that was coupled with a Nikon DS-Fi2 digital camera, applying magnification in the range $100-1,000 \times$. The study was carried out using unetched specimens and specimens etched with a $3 \%$ solution of $\mathrm{HNO}_{3}$, in accordance with the $\mathrm{PN}-\mathrm{H}-$ 04503:1961 guideline. NIS Elements software was used to record and analyze the recorded pictures.

The hardness of the examined specimens was measured with a Zwick/Roel ZHU 187.5 hardness tester using the Brinell method, in accordance with the PN-EN ISO 6506-1:2014-12 guideline. A ball of cemented carbide with a diameter of $2.5 \mathrm{~mm}$ was used. The load was equal to $187.5 \mathrm{kgf}$ $(1,838.7469 \mathrm{~N})$ and applied for over $15 \mathrm{~s}$. All measurements were performed using specimens for which microstructure-examination had been performed previously.

Strength tests were carried out at an ambient temperature on proportional rectangular specimens, in accordance with the PN-EN ISO 68921:2016-09 guideline. An MTS 810 testing ma- chine with an MTS extensometer was used, and the assumed gauge length was $\mathrm{L}_{0}=25 \mathrm{~mm}$. The strain rate was controlled in the tests (Method A) based on the feedback obtained from an extensometer. The range of force used during the tests was $0-250 \mathrm{kN}$. Subsequently, for every specimen, Young modulus (E), ultimate tensile strength $\left(\mathrm{R}_{\mathrm{m}}\right)$, yield strength $\left(\mathrm{R}_{\mathrm{p} 0.2}\right)$, elastic limit $\left(\mathrm{R}_{\mathrm{p} 0.05}\right)$, and the values at rapture in the case of: reduction area $(\mathrm{Z})$ and elongation (A) were determined. The final strength indices were the arithmetic mean of the results for each measuring point obtained from at least five specimens. Additionally, based on the results obtained from testing individual specimens, the standard deviation was calculated from the measurement errors.

Impact tests were carried out in accordance with the PN-EN ISO 148-1:2017-02 guideline using the Charpy hammer (Zwick/Roell RPK300), with an initial energy value equal to $300 \mathrm{~J}$. The study was conducted using cuboid, V-notch specimens. Based on the results obtained at temperatures: $+20{ }^{\circ} \mathrm{C}$, $0{ }^{\circ} \mathrm{C},-20{ }^{\circ} \mathrm{C}$, and $-40{ }^{\circ} \mathrm{C}$, the arithmetic mean from at least five specimens for every measuring point, and the standard deviation of the obtained strength indices, were calculated. Then, fractographic analyses, using a JSM-6610A scanning electron microscope (SEM) manufactured by Jeol, were carried out on the selected facture surfaces. During the test, an acceleration voltage of $20 \mathrm{kV}$ was used. The observation was carried out in material contrast using SE detectors. Based on the recorded images of the fracture surface, the percentage of the ductile zone was calculated using ImageJ ver. 1.52a image analysis software. 
a)

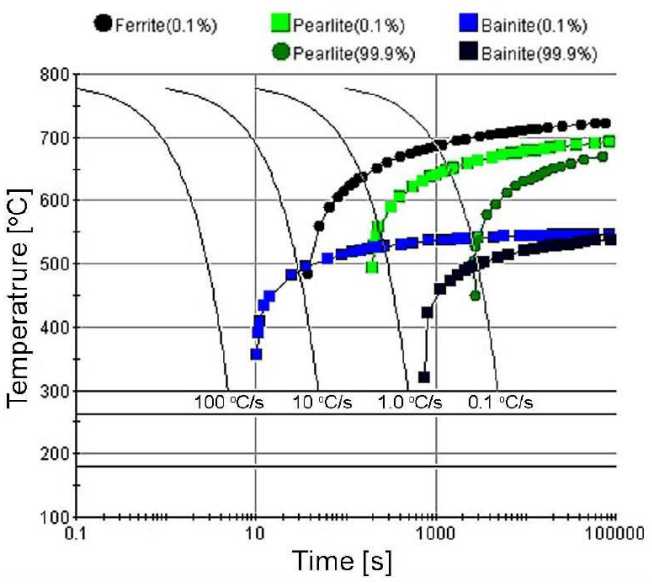

b)

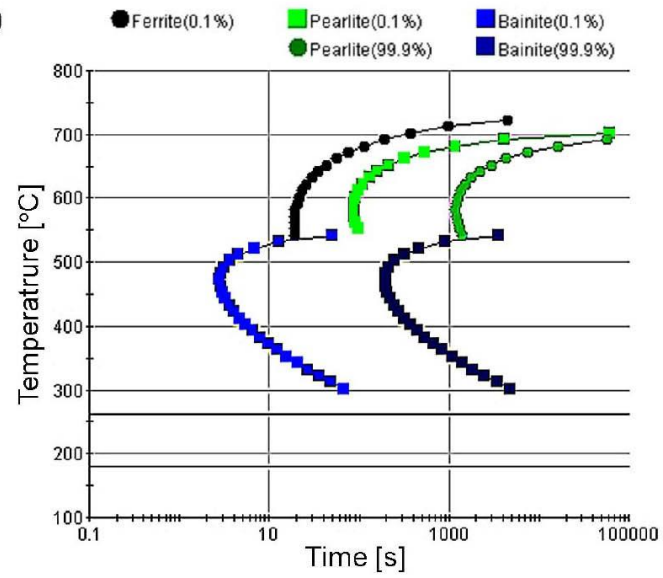

Fig. 1. Time-temperature graph for steel with chemical composition (\% by mass): C-0.44, Si-0.17, Mn- 0.53 , P0.006, S-0.002, Al-0.04, Cr-0.31, Cu-0.01, Co-0.02, Ni-2.03, Mo-0.14, B-0.002, Ti-0.006, V-0.006; austenitized in temperature $\mathrm{T}_{\mathrm{A}}=788^{\circ} \mathrm{C}$, assumed size of the former austenite grain $-10 \mu \mathrm{m}$. (A) Constant cooling - CCT. (B) Isothermal cooling - TTT. Assigned temperatures for individual transformations, phases and components of the structure: pearlite $-708{ }^{\circ} \mathrm{C}$, ferrite $-738^{\circ} \mathrm{C}$, bainite $-550{ }^{\circ} \mathrm{C}$, martensite $(50 \%)-$ $264{ }^{\circ} \mathrm{C}$, martensite $(90 \%)-179{ }^{\circ} \mathrm{C}, \mathrm{M}_{\mathrm{S}}=300{ }^{\circ} \mathrm{C}$.

\section{Results}

\subsection{Chemical composition analysis}

The results of the chemical composition analysis of Hardox 600 steel (Table 2) indicate that there might be immense variation in the conditions in which the steel was manufactured (heat treatment parameters and chemical composition), and that the extent of such variation depends on the thickness of the plate - even within the same steel grade. The determined real percentage of individual elements - with the exception of boron and carbon - was significantly lower than the acceptable maximum values for specific ranges of steel plate thicknesses (Table 1) provided by the manufacturer. The main reason for this is the need to obtain a high (of similar value) level of hardness in the entire cross section of the steel plate, which is the result of the homogeneous structure of the material.

Justifying the claimed high hardness and strength of Hardox 600 steel for a wide range of steel plate thicknesses, hardenability is achieved by the addition of boron (0.002-0.005\% by mass), as well as by the increased amounts of chromium, nickel, and manganese. As a result of the fact that the manufacturer assumes the possibility of employing welding techniques for the technological procedures of cutting and joining Hardox 600 steel plates, and consequently, the occurrence of tempering at temperatures between $250{ }^{\circ} \mathrm{C}$ and $400{ }^{\circ} \mathrm{C}$ in the heat affected zone, the presence of molybdenum in the chemical composition of the steel can be accounted for. The percentage of this element, which is equal to $0.20 \%$ by mass, most frequently prevents the irreversible temper brittleness.

In addition, the study confirmed a very low content of unfavorable substances - mainly sulfur and phosphorus - in the tested steel. Therefore, only a trace presence of these elements in the chemical composition of the analyzed steel may be required to determine the possibility of achieving high strength indices, while ductility is still preserved. In conclusion, a great variability of the chemical composition of Hardox 600 steel must be the result of highly individualized processes used for the thermomechanical forming of metals, which accounts for the achieving of a martensitic structure at any point of the steel plate. 
Table 2. Actual chemical composition of the tested Hardox 600 steel in $12 \mathrm{~mm}$ thick steel plates

\begin{tabular}{ccccccccc}
\hline \multicolumn{1}{l}{} \\
\hline \hline $\mathbf{C}$ & $\mathbf{S i}$ & $\mathbf{M n}$ & $\mathbf{P}$ & $\mathbf{S}$ & $\mathbf{C r}$ & $\mathbf{N i}$ & $\mathbf{M o}$ & $\mathbf{B}$ \\
0.44 & 0.17 & 0.53 & 0.006 & 0.002 & 0.31 & 2.03 & 0.14 & 0.002 \\
$\mathbf{C u}$ & $\mathbf{A l}$ & $\mathbf{T i}$ & $\mathbf{N b}$ & $\mathbf{C o}$ & $\mathbf{V}$ & $\mathbf{Z r}$ & $\mathbf{P b}$ & $\mathbf{A s}$ \\
0.01 & 0.04 & 0.006 & 0.000 & 0.018 & 0.006 & 0.002 & 0.007 & 0.000 \\
\hline
\end{tabular}

\subsection{Microstructural analysis}

The images of Hardox 600 steel's microstructure in its delivery state and after normalizing are presented in Figures 2, 3, 4, 5. In the delivery state, the examined steel has the structure of mediumcarbon martensite, which is in greater part similar to the structure of martensite tempered in a lowtemperature range. Additionally, changes in microstructure in the form of quenched martensite bands (bright areas in Figure 2A and B), pointing to a higher content of carbon, are clearly observed in both rolling directions of the steel plate. The bands are longer and wider in the longitudinal direction. In terms of the morphology of the martensitic structure, the longitudinal direction is characterized by a considerable degree of variability in the crystallographic orientation of the martensitic laths and needles (Figure 3A). In the case of the transverse orientation (Figure 3B), the structure of martensite with a small lath-shaped layout dominates, which in some areas is characterized by an arrangement of blocks and packets. This formation points to the occurrence of an identical martensite crystallographic orientation within individual packets - a low degree of variability of the microstructure.

Normalization brought about significant changes in the microstructure of the Hardox 600 steel (Figures 4 and 5). Generally speaking, it can be said that in the abovementioned heat treatment, the steel is characterized by the structure of quenching sorbite with numerous bands of martensitic structure running in accordance with the orientation of thermomechanical treatment. In selected bands - the bright zones in Figure 4A structures with features of high carbon martensite can be observed. It can be stated that the presence of these zones is closely related to the bands of the martensitic structure, which were also

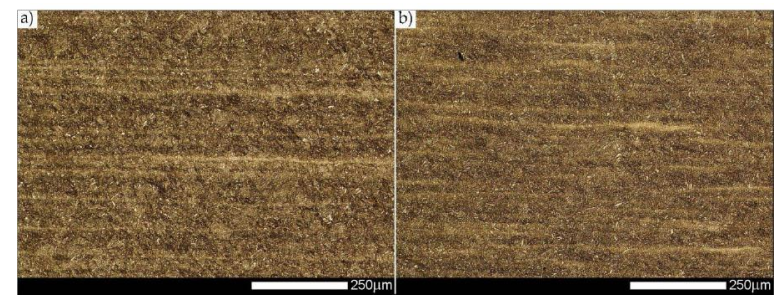

Fig. 2. Hardox 600 steel's microstructure in the delivery state with a clearly distinct banding pattern resulting from thermomechanical rolling. (A) Longitudinal orientation - hardness of 560 HBW. (B) Transverse orientation - hardness of $552 \mathrm{HBW}$. Light microscopy, etched with $3 \%$ $\mathrm{HNO}_{3}$.

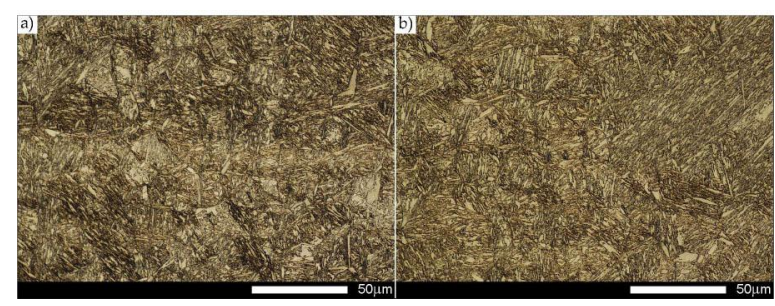

Fig. 3. Magnified image of the central zone of the microphotography that was shown in Figure 2. (A) Longitudinal orientation - tempered martensitelike structure; a locally (in bands) quenched martensite structure. (B) Transverse orientation - tempered martensite-like structure, a mainly small lath structure. Light microscopy, etched with $3 \% \mathrm{HNO}_{3}$.

observed on the specimens in the state of delivery (Figures 2 and 3). This indicates the course of the rolling processes of the Hardox 600 steel plate at a relatively low temperature, which enabled the diffusion processes of elements with a high affinity for carbon. Additionally, in a few areas of the transverse specimen's structure (Figure 5B), apart from the martensite, precipitation of the bainite structure can be observed. 


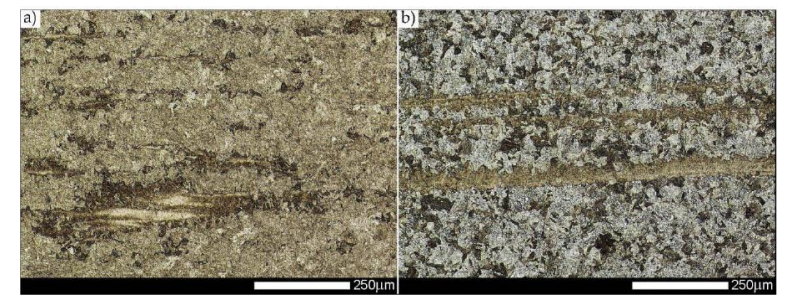

Fig. 4. Hardox 600 steel microstructure in normalized conditions. (A) Longitudinal orientation - hardness of 347 HBW. (B) Transverse orientation - Hardness of 283 HBW. In both cases, the quenched structures exhibit a wide structural diversity with a great percentage of diffusion structures. Light microscopy, etched with $3 \%$ $\mathrm{HNO}_{3}$.

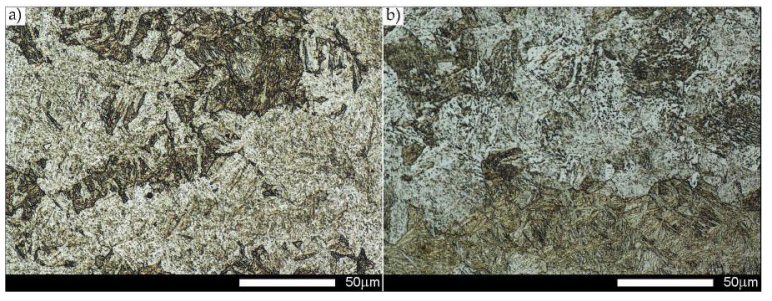

Fig. 5. Magnified image of the central zones of the microphotography that was shown in Figure 4. (A) Longitudinal orientation. (B) Transverse orientation. The microstructures are very similar to each other in terms of their structure mostly consisting of quenching sorbite and needle martensite, and locally - bainite. Light microscopy, etched with $3 \% \mathrm{HNO}_{3}$.

In conclusion, it has to be highlighted that the above description of the selected structural properties of Hardox 600 steel is based on the examinations that deploy light microscopy, SEM, and transmission electron microscopy (TEM). However, due to the fact that the results of selected structural studies for the entire Hardox steel group were reported in, for example, articles [29, 35], and due to the relatively concise nature of this manuscript, a more extensive presentation of the results of the microstructure analysis was not adopted.

\subsection{Tension test}

Figures 6 and 7 show the results of strength tests of the Hardox 600 steel specimens. Based on these results, it can be concluded that steel in the state of delivery has a very high tensile strength $\left(R_{m}\right)$, significantly exceeding the 2,000 $\mathrm{MPa}$ stated by the producer for both rolling orientations (Table 1). The fact deserves to be emphasized that these values were obtained while maintaining very favorable ductile properties that are defined by the elongation $\left(\mathrm{A}_{5}\right)$ and reduction $(\mathrm{Z})$.

The relatively favorable ratio of the apparent yield strength to the ultimate tensile strength $\left(\mathrm{R}_{\mathrm{p} 0.2} / \mathrm{R}_{\mathrm{m}}\right)$ is also worth noting. The coefficient equal to $0.73-0.74$ confirms the steel's ability to strengthen significantly after the yield point is exceeded, which, from an engineering perspective, does not require the application of high safety coefficients for the designed structure. This may be due to the slightly lower value of the yield strength in comparison with the technical specifications. The difference is equal to about $100 \mathrm{MPa}$. The relationships described above, along with the chemical composition (a small number of alloy elements with high affinity for carbon and their percentage by mass), makes it possible to tentatively state that the Hardox 600 steel strength in the state of delivery is primarily due to the changes in the microstructure achieved via the thermomechanical treatment of metals and the excessive carbon oversaturation of a solid solution. The relatively low values of Young modulus and yield strength indicate the presence of precipitation-strengthening mechanisms, which also acts as a safeguard against a dislocation movement.

Normalizing caused a significant decline in all the indices responsible for the steel's strength. Based on the results of the study (Table 1 and Figure 6), it can be estimated that the obtained values of the selected strength parameters in any orientation of steel plate rolling reflected the following relationship to their equivalents of the steel in the delivery state: $\mathrm{R}_{\mathrm{m}}: 40-43 \%, \mathrm{R}_{\mathrm{p} 0.2}: 39-40 \%$, $\mathrm{R}_{\mathrm{p} 0.05}: 36 \%$, HBW: 48-57\%. Normalizing was also responsible for the increase in ductility parameters in the tested steel, i.e., relative elongation by 24-35\%, and reduction area by 17-19\%. When considering the above information and by taking into account the results of the previously presented steel structure analysis (Figures 4 and 5), it can 
be concluded that normalizing induces changes in the mechanical properties in Hardox 600 steel that are very similar to the properties obtained in medium-carbon low-alloy steels that have been heat-treated (quenched and high-tempered). It should be noted, however, that in the case of the studied steel, the obtaining of the structure of tempered sorbite (with no features of post-martensitic orientation), with an ultimate tensile strength of $\mathrm{R}_{\mathrm{m}} \approx 900 \mathrm{MPa}$ derived in the process of cooling it in open air, is largely due to the steel's high hardenability, which is achieved by the micro-addition of boron.

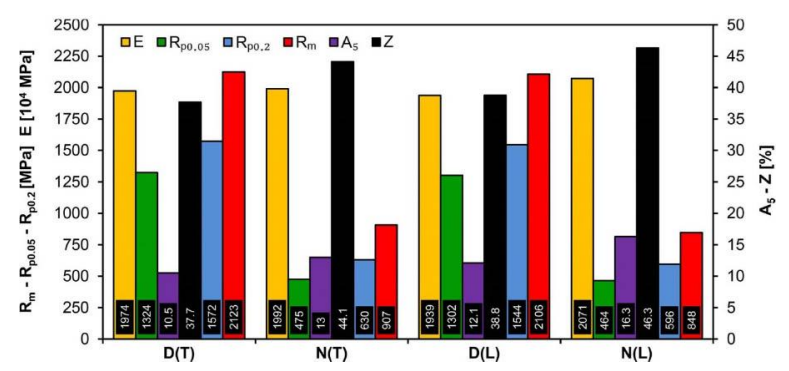

Fig. 6. Selected mechanical properties of Hardox 600 steel based on Table 1: D, state of delivery; N, normalized state; L, longitudinal orientation; $\mathrm{T}$, transverse orientation.

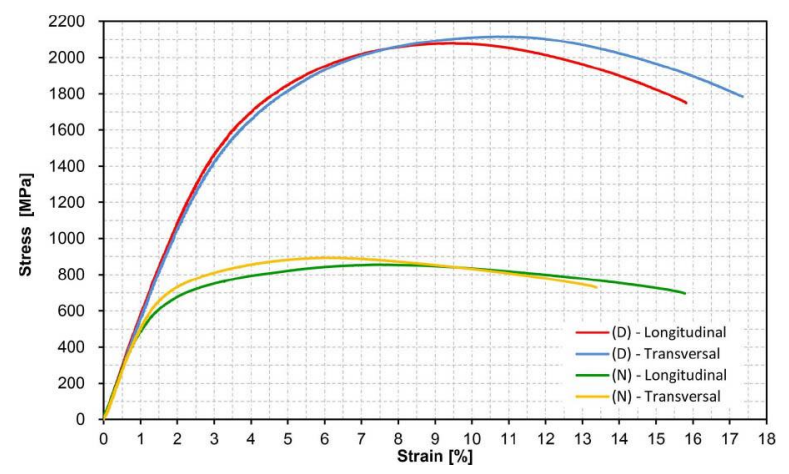

Fig. 7. The stress-strain curves of selected (representative) samples of Hardox 600 steel: D, state of delivery; $\mathrm{N}$, normalized state; $\mathrm{L}$, longitudinal orientation; $\mathrm{T}$, transverse orientation.

The obtained elongation and reduction-in-area parameters after normalization would allow the steel to be classified as ductile material. However, due to the work environment of the working elements for which this steel is intended (abrasive and dynamic loads) and the necessity to join this steel with welding techniques, the authors of this article are of the opinion that a credible assessment of normalized Hardox 600 steel ductility can only be done using impact tests and fractography. Fractographic analysis is an indispensable study here, because the experience of the authors obtained during research on this group of materials shows that there are discrepancies in the assessment of ductility based on the results obtained from the impact strength test and the nature of the fracture. This standpoint is adopted due to the occurrence of the diffusive transformation of carbon and alloy micro-additives (mainly chromium, molybdenum, and boron) during the cooling process of Hardox 600 steel, which is conducive to the precipitationstrengthening mechanism. This can be confirmed by the elevated Young modulus, which is comparable to the one in the delivery state steel and which can especially be observed along the longitudinal orientation of the tested steel.

\subsection{Impact test}

Figure 8 presents the results of the impact tests for Hardox 600 steel in the state of delivery, and also the results for the normalized steel. If we assume a toughness equal to $35 \mathrm{~J} / \mathrm{cm}^{2}$, which is equivalent to $50 \%$ of the brittle fracture considered as the material brittleness threshold [42], it can be concluded that in the state of delivery (longitudinal orientation), the tested steel fulfills the criterion at the temperature range of $-20{ }^{\circ} \mathrm{C}$ to $+20{ }^{\circ} \mathrm{C}$. For the transversal orientation, the tested steel fulfills the criterion at the temperature beyond $+5{ }^{\circ} \mathrm{C}$. Nevertheless, the impact toughness values for both orientations are very similar to each other, and the above demarcation of the ductile-to-brittle transition temperatures is only indicative. The above statement is due to the fact that Hardox 600 steel, when in the state of delivery, does not show a clear ductileto-brittle transition character. At the temperature of $-40{ }^{\circ} \mathrm{C}$, the obtained mean value of impact toughness is below the adopted criterion of brittleness. However, the deviation is not significant and does 
not run incrementally. It is worth noting that the registered course of changes in the toughness of Hardox 600 steel in the delivery status is of a balanced nature and is virtually identical for both orientations of rolling.

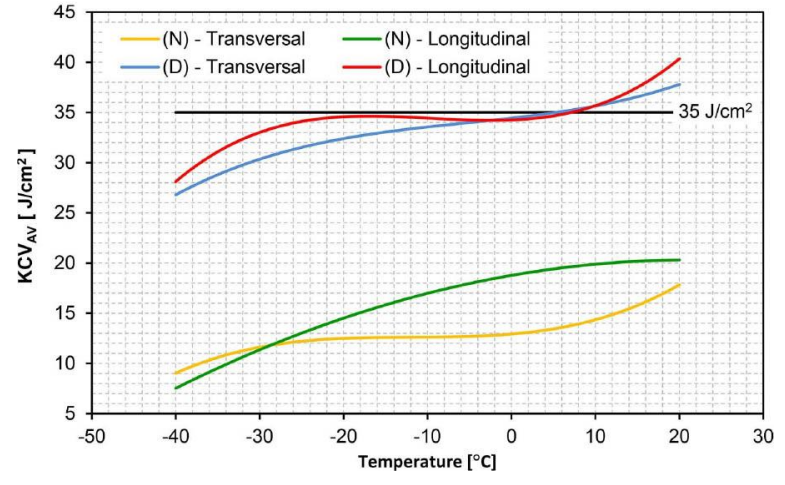

Fig. 8. The ductile-to-brittle transition temperatures of Hardox 600 steel - based on Table ??: D, state of delivery; $\mathrm{N}$, normalized state.

In the normalized state, according to predictions made during the strength tests, the impact strength of Hardox 600 steel in all the test temperature ranges, not including the orientation of the thermomechanical treatment, was lower than the adopted brittleness threshold of $35 \mathrm{~J} / \mathrm{cm}^{2}$. So, it can be concluded that the mechanical properties, especially the impact characteristics, got "degraded" in the normalized state compared to the state of delivery. The above conclusion can be especially significant for deciding the application of heat processes in joining and treating Hardox 600 steel plates, which may eventually lead to their brittle fracture - even at ambient temperature.

\subsection{Fractographic analysis}

Figures 9 and 10 present representative images of Hardox steel 600 fracture surfaces, in the state of delivery from the manufacturer and in the normalized state, respectively. Fractographic analyses were performed on the specimens that were subjected to impact tests at temperatures of $+20^{\circ} \mathrm{C}$ and $-40{ }^{\circ} \mathrm{C}$. Based on the macroscopic images of the fractures in the Hardox 600 steel in the state of delivery (Figure 9), it can be concluded that the fractures are characterized by a significant percentage

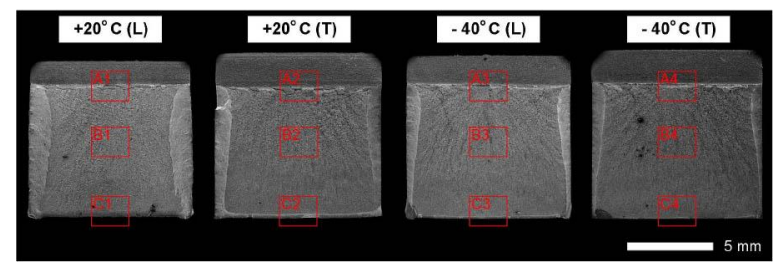

Fig. 9. Macroscopic image of fractures in representative specimens of the Hardox 600 steel in the state of delivery: L, longitudinal orientation; T, transverse orientation; frames are used to mark: $\mathrm{A}$ - the zone below the notch; B - the central zone; $\mathrm{C}$ - the final-fracture zone. SEM, scanning electron microscopy.

of ductile edge zones for both metal-rolling orientations - especially at ambient temperatures. This indicates a relatively high energy expenditure during their formation.

The obtained mean values of impact strength at the temperature of $+20{ }^{\circ} \mathrm{C}$ that are equal to $40.3 \mathrm{~J} / \mathrm{cm}^{2}$ and $37.8 \mathrm{~J} / \mathrm{cm}^{2}$ for longitudinal and transverse orientations, respectively, appear to confirm the above conclusion. The percentage of ductile fractures in the edge zones markedly decreases in relation to temperature. However, at the temperature of $-40{ }^{\circ} \mathrm{C}$, the presence of plastically deformed edge zones in the specimens subjected to the impact tests is still registered, especially immediately below the mechanical notch. Taking the very high static strength index of Hardox 600 steel in the state of delivery into account, the values obtained for both orientations of rolling, which are equal to $28.1 \mathrm{~J} / \mathrm{cm}^{2}$ and $26.8 \mathrm{~J} / \mathrm{cm}^{2}$, respectively, ought to be recognized as very advantageous and relatively safe from the engineering perspective.

Normalized steel, on the other hand, demonstrated no significant percentage of ductile edge zones on the exposed fracture surfaces at practically any temperature range during the impact tests (Figure 10). This feature indicates a low energy expenditure in the cracking process of the specimens [42, 43], and the presence of this feature is also ascertainable through the obtained values of impact strength whose range is from $7.7 \mathrm{~J} / \mathrm{cm}^{2}$ to $20.1 \mathrm{~J} / \mathrm{cm}^{2}$ for both orientations of thermomechanical treatment in the whole range of tempera- 
tures. To expose the detailed structure of individual zones, selected fracture surfaces were subjected for further analyses using SEM (Figures 11, 12, 13, 14, $15,16,17,18,19,20,21,22,23,24,25,26,27,28)$.

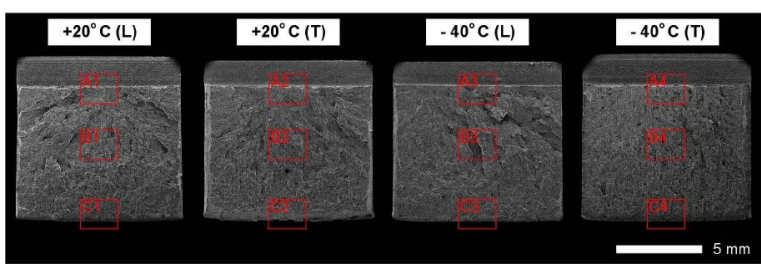

Fig. 10. Macroscopic image of fractures in representative specimens of the Hardox 600 steel in normalized state: $\mathrm{L}$ - longitudinal orientation, $\mathrm{T}-$ transverse orientation; frames are used to mark: A - the zone below the notch; $\mathrm{B}$ - the central zone; $\mathrm{C}$ - the final-fracture zone. SEM, scanning electron microscopy.

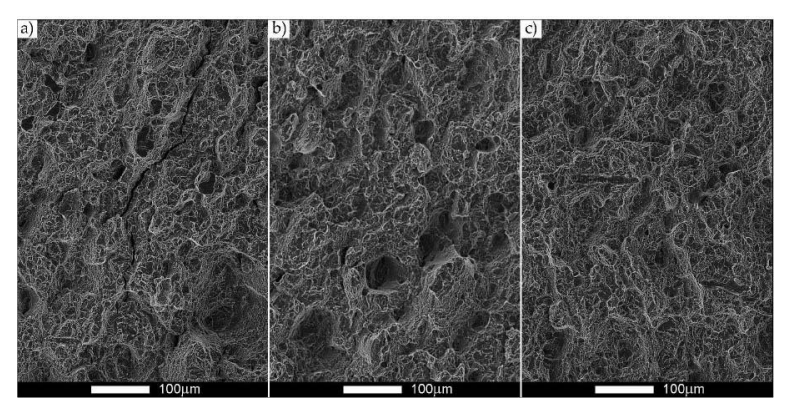

Fig. 11. Images of the Hardox 600 steel fracture surface in the state of delivery that was shown in Figure 9: longitudinal orientation $\left(+20^{\circ} \mathrm{C}\right)$. (A) The area marked with the A1 frame, ductile zone $\approx 63 \%$. (B) The area marked with the $\mathrm{B} 1$ frame, ductile zone $\approx 50 \%$. (C) The area marked with the $\mathrm{C} 1$ frame, ductile zone $\approx 57 \%$.

The fractures in the Hardox 600 steel specimens in the state of delivery, shown in Figures 11, 12, 13, $14,15,16,17,18,19$ and analyzed both at ambient and lowered temperatures, are mixed-mode fractures. Numerous dimple-shaped areas, which are separated by ductile areas - locally with the formation of slip bands in the form of "fish scales" - are observed on the surface of the specimens (marked with arrows FS in Figures 12, 14, 16, 18, and 19). This kind of structure can be seen most frequently in the area of the fracture - where the steel has a clearly fragmented microstructure. This topographic structure of a fracture is seen during the impact tests in both orientations of the rolling of the steel plates and in the whole range of temperatures. It appears as a result of sliding and decohesion of the crystallographic structure, which can be seen in the formation of microfractures in the form of overlapping scales along the planes [43]. The dimple structure (Figure 19) seen on the surface of the fracture, on the other hand, has a parabolic contour, which shows that cracks are initiated with ductile deformation - a slide resultant from static forces along specific crystallographic planes. Phase precipitation arising as a direct result of chemical composition and thermomechanical rolling cannot be observed inside the dimples. As a result of the fact that most exposed surfaces demonstrate a characteristic, river-like morphological pattern (marked with RP in Figures 12 and 14), definite identification of the above planes is virtually impossible. This can be explained by the fact that the formation of a dimple structure over a vast surface, which is characteristic for a ductile fracture, results from the "meandering" phenomenon of the "river" system that was described above.

It is worth mentioning that increasing the ability to absorb energy during the cracking process, and thus decreasing the brittleness threshold, is commonly associated with the appearance of steps in the process of mixed-mode cracking (arrows $S$ in Figures 12 and 14). In the evaluated steel, the occurrence of slip bands is of a limited extent. Additionally, in all Hardox 600 steel fractures in the state of delivery, extensive cracks (marked as intercrystalline cracks (IC) and secondary cracks (SC) in Figures 12, 14, 16, 18, and 19), which are most often aligned with the orientation of the main tensions during load-bearing, can be seen in macroscopic examinations. It can be concluded that their alignment along the cleavage plane is of a transcrystalline nature in the overwhelming majority of cases (Figure 19B).

Figures 20, 21, 22, 23, 24, 25, 26, 27, 28 show representative images of fractures in the normalized Hardox 600 steel specimens. On scrutiny of the images, it can be surmised that the structure of 


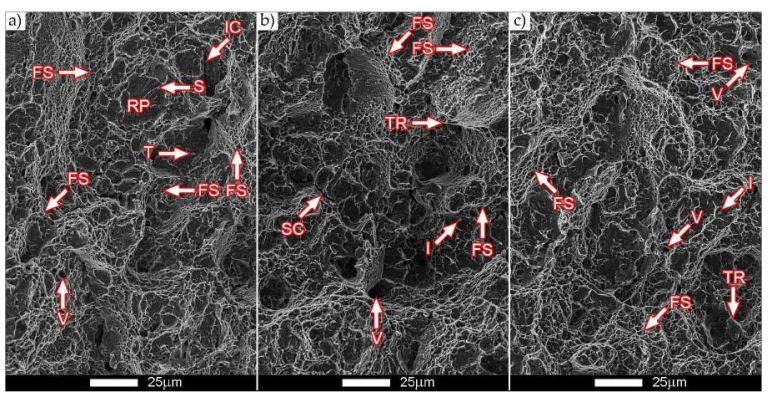

Fig. 12. Magnification of the central zones of the respective images that were shown in Figure 11. SC, secondary crack; IC, intercrystalline crack; $\mathrm{RP}$, "river" pattern; S, steps; T, tongues; V, micro-voids; FS, fish scales; I, inclusions; TR, tear ridges.

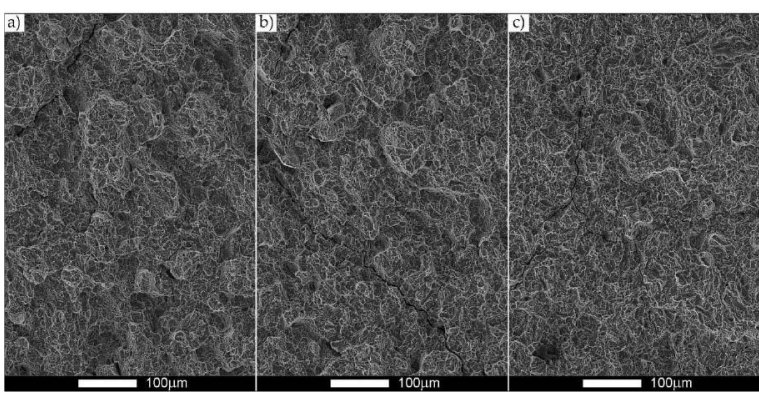

Fig. 13. Images of the Hardox 600 steel fracture surface in the state of delivery that was shown in Figure 9: transverse orientation $\left(+20{ }^{\circ} \mathrm{C}\right)$. (A) The area marked with the A2 frame, ductile zone $\approx 55 \%$. (B) The area marked with the B2 frame, ductile zone $\approx 57 \%$. (C) The area marked with the $\mathrm{C} 2$ frame, ductile zone $\approx 50 \%$.

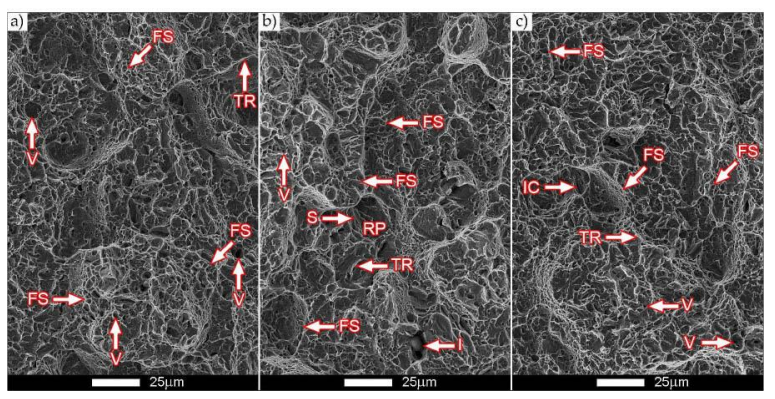

Fig. 14. Magnification of the respective central zones of images that were shown in Figure 13. IC, intercrystalline crack; RP, "river" pattern; S, steps; V, micro-voids; FS, fish scales; I, inclusion; TR, tear ridges.

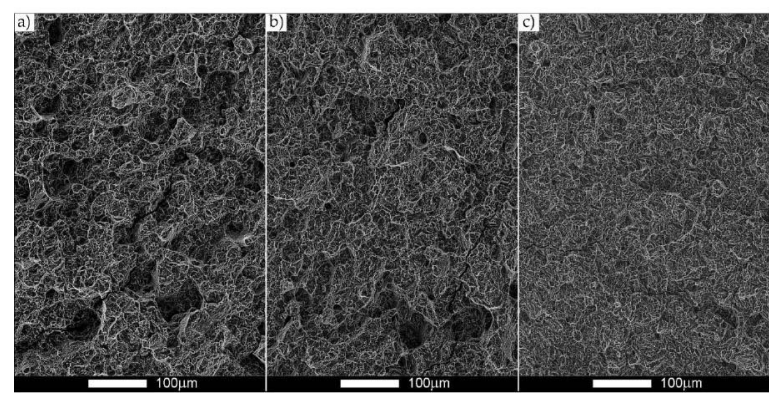

Fig. 15. Images of the Hardox 600 steel fracture surface in the delivery state that was shown in Figure 9: longitudinal orientation $\left(-40^{\circ} \mathrm{C}\right)$. (A) The area marked with the A3 frame, ductile zone $\approx 55 \%$. (B) The area marked with the B3 frame, ductile zone $\approx 53 \%$. (C) The area marked with the $\mathrm{C} 3$ frame, ductile zone $\approx 60 \%$.

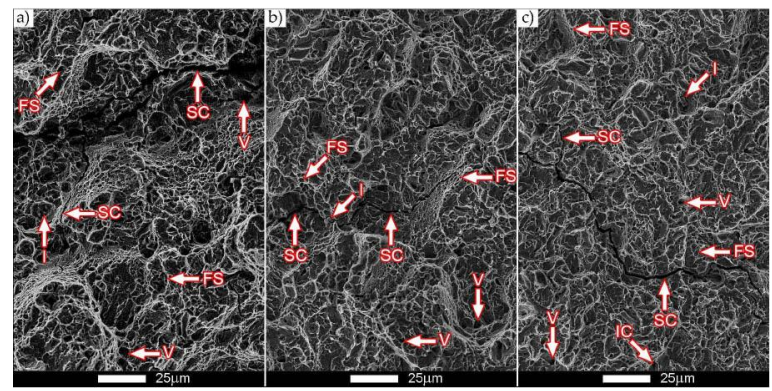

Fig. 16. Magnification of the central zones of the respective images that were shown in Figure 15 . SC, secondary cracks; IC, intercrystalline crack; V, micro-voids; FS, fish scales; I, inclusions.

the fractures is characteristic for brittle fractures, irrespective of the temperature in the impact test. Ductile zones are scarce, and most frequently make up a river-like and river-basin pattern (marked as $\mathrm{RP}$ in Figures 21, 23, 25, 27B, and 27C). Moreover, they are aligned with the main crack orientation. This shows that a considerable amount of energy was absorbed while cracking [42, 43], which is additionally confirmed by the local, fish scale structure that is situated on the boundaries of the grains (marked with arrows FS e.g. in Figures 21C, 23C, 25B, 27A, and 28B).

However, it requires to be highlighted that this kind of structure is only present in individual, 


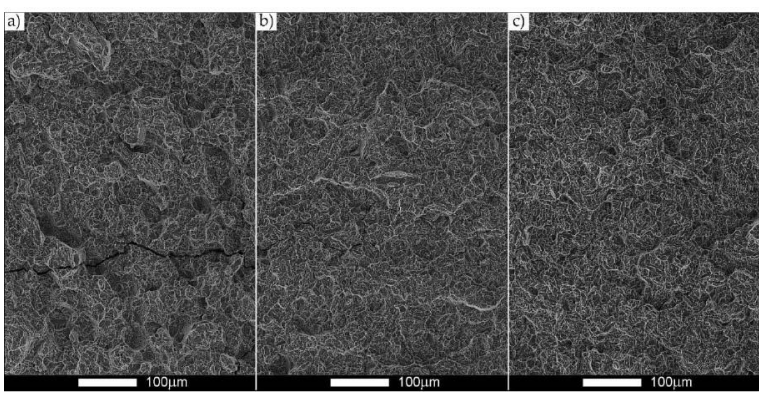

Fig. 17. Images of the Hardox 600 steel fracture surface in the state of delivery that was shown in Figure 9: transverse orientation $\left(-40^{\circ} \mathrm{C}\right)$. (A) The area marked with the A4 frame, ductile zone $\approx 46 \%$. (B) The area marked with the $\mathrm{B} 4$ frame, ductile zone $\approx 46 \%$. (C) The area marked with the $\mathrm{C} 4$ frame, ductile zone $\approx 39 \%$.

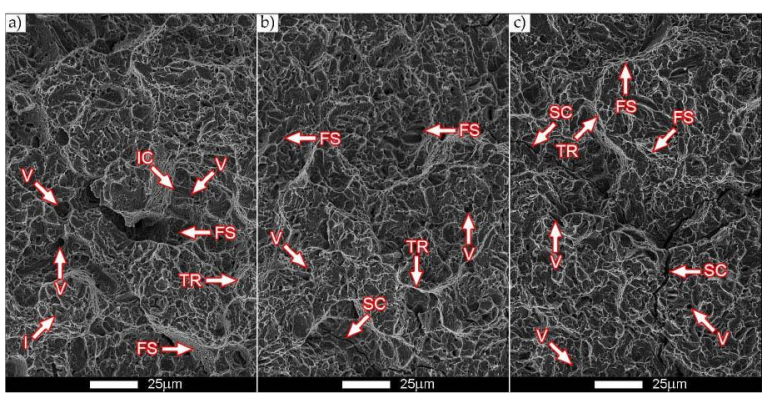

Fig. 18. Magnification of the central zones of the respective images that were shown in Figure 17. SC, secondary cracks; IC, intercrystalline crack; V, micro-voids; FS, fish scales; I, inclusion; TR, tear ridges.

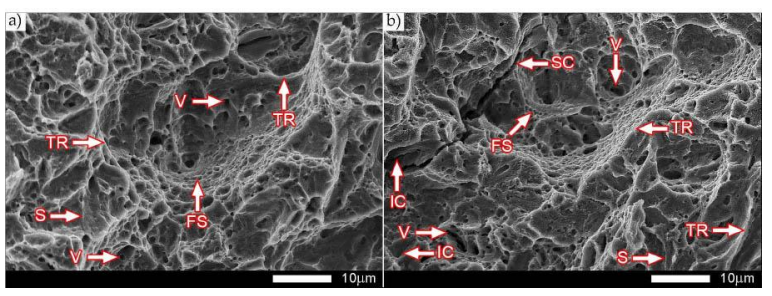

Fig. 19. Magnification of the selected fracture zones of the Hardox 600 steel in the state of delivery that was shown in Figure 9. (A) The area marked with the $\mathrm{C} 2$ frame, transverse orientation $\left(+20{ }^{\circ} \mathrm{C}\right)$. (B) The area marked with the $\mathrm{C} 4$ frame, transverse orientation $\left(-40^{\circ} \mathrm{C}\right)$. SC, secondary crack; IC, intercrystalline cracks; S, steps; V, micro-voids; FS, fish scales; TR, tear ridges.

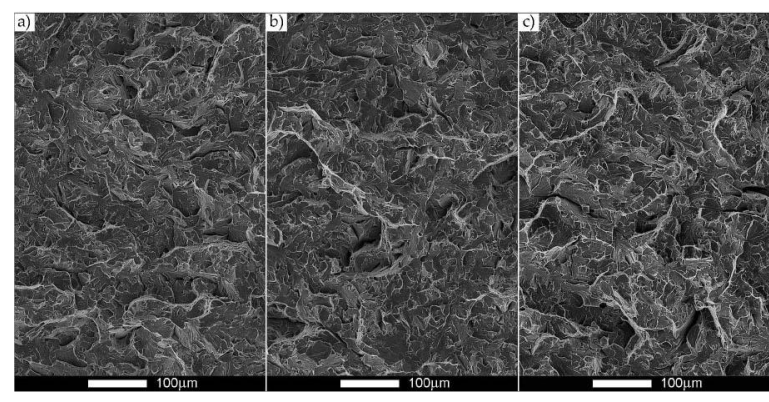

Fig. 20. Images of the surface of the fracture in normalized Hardox 600 steel, which was shown in Figure 10: longitudinal orientation $\left(+20^{\circ} \mathrm{C}\right)$. (A) The area marked with the A1 frame, ductile zone $\approx 18 \%$. (B) The area marked with the B1 frame, ductile zone $\approx 23 \%$. (C) The area marked with the $\mathrm{C} 1$ frame, ductile zone $\approx 16 \%$.

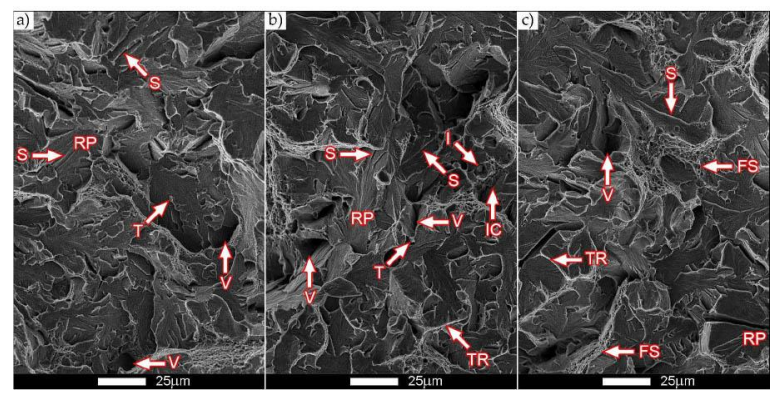

Fig. 21. Magnification of the central zones of the respective images that are shown in Figure 20. IC, intercrystalline crack; RP, "river" patterns; $\mathrm{S}$, steps; T, tongues; V, micro-voids; FS, fish scales; I, inclusion; TR, tear ridges.

highly fragmented areas. In addition, the fractures of the normalized steel subjected to this analysis reveal secondary ICs with a RP located on the surface of the facets.

Based on the results of the impact tests and fractographic analysis, it can be ascertained that the normalizing of Hardox 600 steel leads to the degradation of its impact strength; this degradation is manifested as the reduction in the absorbed energy of the impact test to a value that is below an acceptable level of brittleness. It must be added that the process occurs in all temperature ranges, i.e. from $-40{ }^{\circ} \mathrm{C}$ to $+20^{\circ} \mathrm{C}$, irrespective of the rolling direction of the steel plate. The observed phenomenon - the overwhelming brittle fracture percentage - 


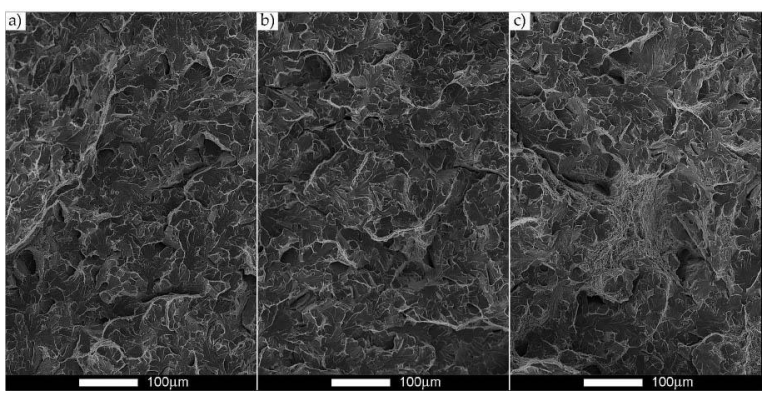

Fig. 22. Images of the surface of the fracture in normalized Hardox 600 steel, which was shown in Figure 10: transverse orientation $\left(+20{ }^{\circ} \mathrm{C}\right)$. (A) The area marked with the A2 frame, ductile zone $\approx 20 \%$. (B) The area marked with the $\mathrm{B} 2$ frame, ductile zone $\approx 19 \%$. (C) The area marked with the $\mathrm{C} 2$ frame, ductile zone $\approx 21 \%$.

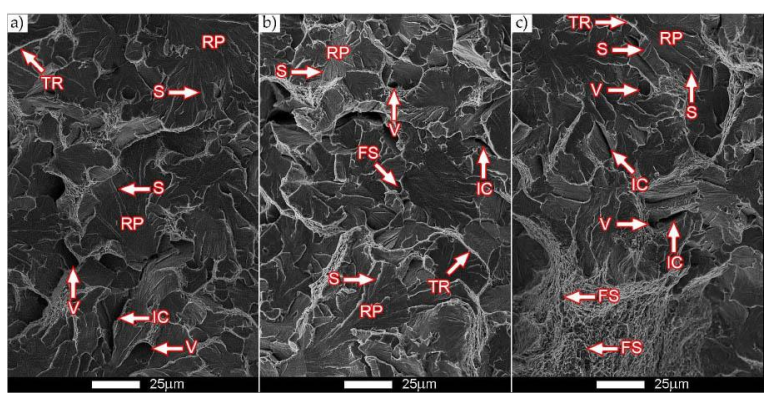

Fig. 23. Magnification of the central zones of the respective images that were shown in Figure 23. IC, intercrystalline cracks; RP, "river" patterns; S, steps; V, micro-voids; FS, fish scales; TR, tear ridges.

is characteristic of ferrite-pearlite steel or pearlite steel [43]. As for Hardox 600 steel in the state of delivery, the toughness for either orientation of metal-rolling at the ambient temperature exceeds $35 \mathrm{~J} / \mathrm{cm}^{2}$, and the fractures are additionally characterized by wide lateral ductile zones. At lower temperatures, a slight reduction in toughness can be observed. However, a clear downward tendency can be observed at a temperature of $-40{ }^{\circ} \mathrm{C}$. It should be highlighted that when the toughness is reduced, no clear change in relationship between the brittle and ductile zones on the exposed fracture surfaces can be observed. Another interesting fact in the discussed case is the presence of dimple-shaped areas in all temperature ranges. According to the litera-

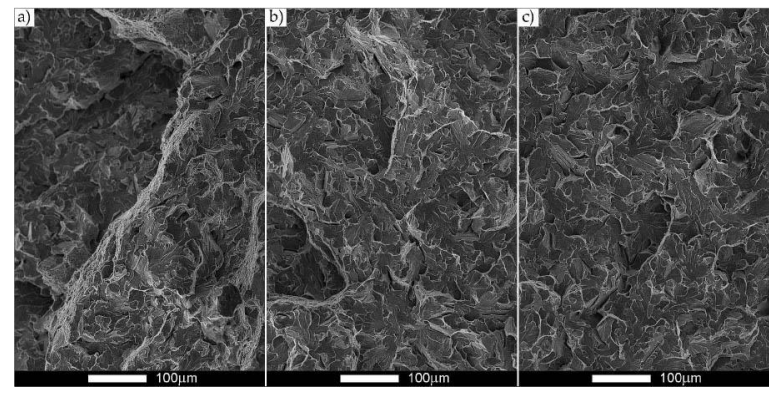

Fig. 24. Images of the surface of the fracture in normalized Hardox 600 steel, which was shown in Figure 10: longitudinal orientation $\left(-40^{\circ} \mathrm{C}\right)$. (A) The area marked with the A3 frame, ductile zone $\approx 15 \%$. (B) The area marked with the $\mathrm{B} 3$ frame, ductile zone $\approx 15 \%$. (C) The area marked with the $\mathrm{C} 3$ frame, ductile zone $\approx 14 \%$.

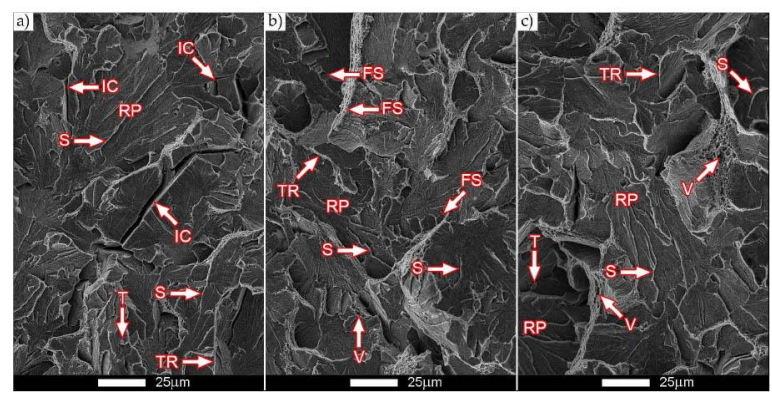

Fig. 25. Magnification of the central zones of the respective images that were shown in Figure 24. IC, intercrystalline cracks; RP, "river" patterns; $\mathrm{S}$, steps; T, tongues; V, micro-voids; FS, fish scales; TR, tear ridges.

ture $[44,45]$, this kind of fractographic structure is characteristic of steels with a tempered martensitic structure.

\section{Conclusions}

The conducted impact tests of Hardox 600 steel confirmed the high strength parameters mentioned in the technical specifications. Irrespective of the metal's thermomechanical rolling orientation, the value of the ultimate tensile strength of the tested steel exceeded $R_{m}$ 2,100 MPa, while ductile properties, i.e., elongation $\left(\mathrm{A}_{5}\right)$ and reduction area $(Z)$, were maintained at a high level. Normalizing provoked significant changes in the structure of Har- 


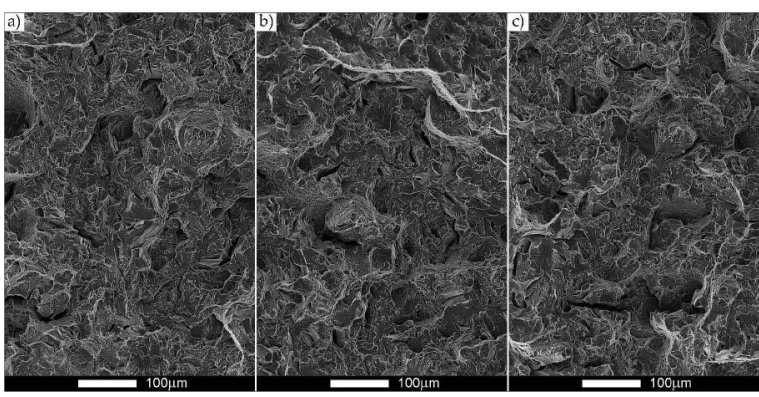

Fig. 26. Images of the surface of the fracture in normalized Hardox 600 steel, which was shown in Figure 10: transverse orientation $\left(-40^{\circ} \mathrm{C}\right)$. (A) The area marked with the A4 frame, ductile zone $\approx 28 \%$. (B) The area marked with the B4 frame, ductile zone $\approx 21 \%$. (C) The area marked with the $\mathrm{C} 4$ frame, ductile zone $\approx 27 \%$.

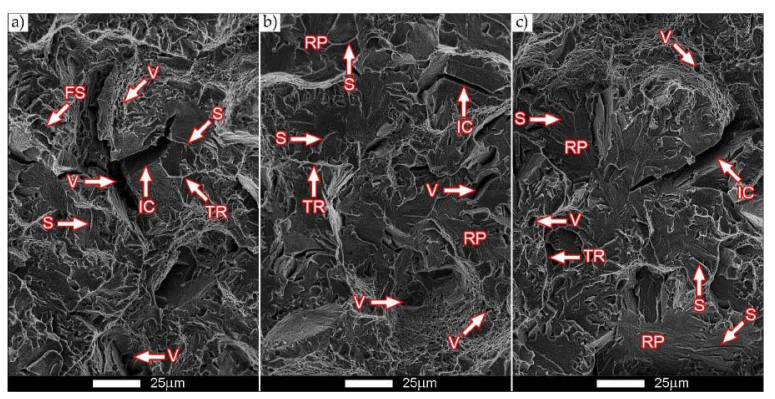

Fig. 27. Magnification of the central zones of the respective images that were shown in Figure 26. IC, intercrystalline cracks; RP, "river" patterns; S, steps; V, micro-voids; FS, fish scale; TR, tear ridges.

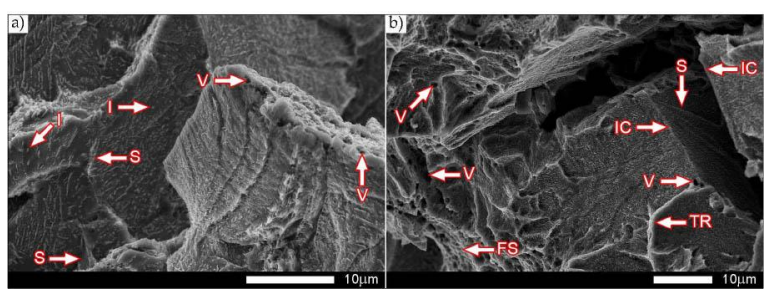

Fig. 28. Magnification of the selected zones of the fracture in normalized Hardox 600 steel, which were shown in Figure 10. (A) The area marked with the $\mathrm{B} 3$ frame, longitudinal orientation $\left(-40{ }^{\circ} \mathrm{C}\right)$. (B) The area marked with the $\mathrm{A} 4$ frame, transverse orientation $\left(-40^{\circ} \mathrm{C}\right)$. IC, intercrystalline crack; S, steps; V, micro-voids; FS, fish scale; I, inclusions; TR, tear ridges. dox 600 steel, which in consequence resulted in markedly reduced strength parameters. Although such parameters as $R_{m}, R_{p 0.2}$, and $R_{p 0.05}$ were halved, increases of 24-35\% in ductility for relative elongation $\left(\mathrm{A}_{5}\right)$ and $17-19 \%$ for reduction area $(Z)$ were recorded in both rolling directions of the metal.

In the context of the conducted impact tests in which the acceptable brittleness threshold was adopted at the level of toughness equal to $35 \mathrm{~J} / \mathrm{cm}^{2}$, which corresponded to $50 \%$ of ductile and brittle fracture, it can be concluded that Hardox 600 steel in the state of delivery (in longitudinal orientation) meets this criterion in the temperature range from $-20{ }^{\circ} \mathrm{C}$ to $+20{ }^{\circ} \mathrm{C}$. For the transverse direction, the above criterion is met in the temperature range from $+5{ }^{\circ} \mathrm{C}$ to $+20{ }^{\circ} \mathrm{C}$.

At the temperature of $-40{ }^{\circ} \mathrm{C}$, a decrease in impact strength of the tested steel was observed, and was equal to $28.1 \mathrm{~J} / \mathrm{cm}^{2}$ and $26.8 \mathrm{~J} / \mathrm{cm}^{2}$ in the longitudinal and transverse orientations, respectively. Due to the above, the temperature threshold of $-40{ }^{\circ} \mathrm{C}$ for Hardox 600 steel in the state of delivery can be adopted. Normalized steel, however, does not meet the adopted criterion in any temperature range. Consequently, it can be concluded that the transition of normalized steel into a brittle state occurs at an ambient temperature, which clearly indicates the fact that heat-induced unfavorable changes occur, which hamper the optimality of its performance.

The macroscopic analyses of the fracture surfaces did not reveal any considerable disparities between qualitative and quantitative criteria of brittleness. The percentage of ductile zones on the surface of the fracture in Hardox 600 steel in the state of delivery in both longitudinal and transverse orientations (subjected to tests in the whole temperature range, i.e., between $-40{ }^{\circ} \mathrm{C}$ and $+20{ }^{\circ} \mathrm{C}$ ) was equal to $39-60 \%$, which ensures a high level of resistance to dynamic load.

Normalized Hardox 600 steel, in virtually none of the discussed cases, showed any clear traces of ductile deformity in the impact-tested specimens, especially in the lateral zones and directly below the mechanical notch. In the exposed fracture's surfaces, a brittle fracture with a characteristic river- 
like pattern and with few ductile zones was predominant. The estimated percentage (up to $30 \%$ ) of ductile zones confirms the presence of unfavorable structural changes caused by normalization.

Therefore, taking into account the high strength parameters of Hardox 600 steel, in conjunction with satisfactory impact toughness, an analysis was undertaken focusing on potential (real) applications, in which the starting point was the selection of machine elements that are highly exposed to intense abrasive wear when combined with dynamic impact of excavated material in which the use of steel with such mechanical properties would be justified both from an engineering and economic point of view. Undoubtedly, the application proposals presented below require comprehensive operational tests. However, the obtained results of laboratory tests enable their correct and optimal planning. As an example for deviations from the above course of the procedure, it is probable that the first attempt to use Hardox steel in opencast mines in Poland were made almost 20 years ago. At the "Konin" Brown Coal Mine, Hardox 400 was used for the bucket blades. Results of that experiment were completely negative. Hardox 450 steel (durability of about 3 months), used for transfer station in the aggregate mine near Walbrzych in Poland, also received a very negative assessment [9]. In this case, the reasons for the worse-than-expected operating behavior of Hardox 450 come down to unfavorable changes in the structure in the heat-affected zones of the welded joints, which are numerous, especially in the case of a bucket knife.

On the basis of many years of research experience related to high-strength steels resistant to abrasion, the authors take the position that the method of obtaining and presenting guidelines for joining the tested steel with welding techniques should be treated only as recommendations. The authors have already made attempts to develop an appropriate welding technology dedicated to Hardox 600, which has displayed promising results. On the basis of the obtained preliminary results, this material is considered as a prospective candidate in at least a few construction units of machines.

To summarize, scientific and technical progress in the aspect of material selection allows the consideration of issues related to material degradation in terms of increasing the quality and durability of machine assemblies. Qualitatively new possibilities are created by the use of low-alloy martensitic steels in place of the elements that work under conditions of abrasive wear and dynamic loads, provided that - other than those commonly used the welding technologies and heat treatment of the welded joints of low-alloy martensitic steels are refined. In the context of the above considerations, the main areas of application of Hardox 600 can be indicated as the following:

1. Mining industry:

- Linings of conveyors

- Linings of vibrating and drawer baskets

- Teeth and blades of excavator buckets

- Highly loaded areas of the bucket wheel chute

2. Transport industry:

- Floors and walls of semi-trailers, trailers and containers

- Floors and sides of haul trucks, dump trucks

- Drums of concrete mixers

- Sieves

3. Construction industry:

- Plating, bucket shells of excavators, loaders, crushers, shears

One should be aware that there are many factors that underlie the selection of an appropriate material solution, including, apart from technical, both environmental and economic factors. Contemporary trends assume greater and greater performance of machines and devices, which entails the intensification of wear processes and their negative impact on the environment. These tendencies are especially visible in those countries where a relatively large number of minerals are extracted from mining in opencast mines. Consequently, there is a great 
demand for new engineering materials. The performed laboratory tests, supplementing the knowledge concerning wear-resistant materials with a static strength exceeding 2,000 MPa, undoubtedly fit into the trend of searching for materials that meet the environmental requirements in opencast mines. Thus, they become the starting point for research on technological and operational properties of these steels. It is also worth emphasizing that this significant influence of the environment, which determines the durability of machines and devices, may in a sense be limited consequent to the solutions of the modern steel industry. As a result of the growing consumption, the increasing global demand for energy, fast transport, and extensive road networks will not allow opencast mines to disappear from the landscape for a long time. However, consequent to the use of modern, high-strength materials, the mining industry may have a less destructive influence on the environment, primarily by reducing the emission of harmful greenhouse gases from equipment and working machines.

\section{References}

[1] Neale M., Gee M., A guide to wear problems and testing for industry. Amsterdam: Elsevier; 2001.

[2] Waroch M., Brown Coal. 2005; 1(50):21.

[3] Borcz A., Kozioł W., Mod Build Eng. 2015; 4(61):102.

[4] Babiarz S., Dudek D., Chronicle of failures and catastrophes of basic machines in Polish opencast mining. Wroclaw: Publishing House of Wrocław University of Science and Technology; 2007.

[5] Dudek D., Nowakowski T., Resilience engineeringagents of open pit mining machine disasters in Poland. In: SOKOLSKI M., editor. Mining machines and earthmoving equipment. Cham: Springer; 2020. p. 1.

[6] Djurić R., Milisavljević V., Ekspolat Niezawodn. 2016; 18(1):142.

[7] Dudziński W., Pękalski G., Brown Coal. 2011; 34(52):5.

[8] Kowalczyk M., Czmochowski J, Rusiński E., Ekspolat. Niezawodn. 2009; 11(2):17.

[9] Pękalski G., Mucha T., Lipińska A., Brown Coal. 2011; 3-4(52):10.

[10] Sundström A., Rendón J., Olsson M., Wear. 2001; 250(1-12):744.

[11] Chintha A.R., Valtonen K., Kuokkala V.-T., Peet M.J., Bhadeshia H.K.D.H., Wear. 2019; 430:428-429.

[12] Chintha A.R. Mater Sci Tech-Lond. 2019;35(10):1133.

[13] HARDOX. https://www.ssab.com/products/ brands/hardox. Accessed 15 Oct 2020.

[14] STAL-HURT. https://www.stal-hurt.com. Ac- cessed 15 Oct 2020.

[15] https://www.abraservice.com/products/ abrasion-resistant-steels/creusabro-8000. Accessed 15 Oct 2020.

[16] https://www.flinkenberg.fi/wp-content/ uploads/DATASHEET-XAR600.pdf. Accessed 15 Oct 2020.

[17] Bugacki H., Smajdor M., Adv Mater Sci. 2003; 4(2):5.

[18] Uzunali U.Y., Cuvalci H., The effects of post weld heat treatment on the mechanical properties of tempered martensite and high strength steel welded joints. Advances in Structural Engineering and Mechanics (ASEM15), Incheon, Korea; 2015.

[19] Mazur M., Ulewicz R., Bokůvka O., Mater Eng. 2014; 21:122.

[20] Frydman S., Konat Ł., Pękalski G., Arch Civ Mech Eng. 2008; VIII(4): 15.

[21] Konat Ł., Metals-Basel. 2019; 9(9):915.

[22] Konat Ł., Białobrzeska B., Białek P., Metal-Basels. 2017; 7(9):349.

[23] Konat Ł., Napiórkowski J., Białobrzeska B., Tribologia. 2017; 273(3):67.

[24] Napiórkowski J., Konat Ł., Ligier K., Tribologia. 2016; 269(5): 105.

[25] Białobrzeska B., Konat Ł., Tribologia. 2017; 272(2):7.

[26] Napiórkowski J., Konat Ł., Pietruszewska M. Tribologia. 2018; 280(4):.

[27] Napiórkowski J., Lemecha M., Konat Ł., Tribologia. 2017; 273:111.

[28] Konat Ł., Napiórkowski J., Kołakowski K., Tribologia. 2016; 268(4):101.

[29] Konat Ł., Structures and properties of Hardox steels and their application possibilities in conditions of abrasive wear and dynamic loads. Wroclaw: Publishing House of Wrocław University of Science and Technology; 2007.

[30] Cegiel L., Konat Ł., Pawłowski T., Pękalski G., Brown Coal. 2006; 3(56):24.

[31] Dudziński W., Konat Ł., Białobrzeska B., Arch Metall Mater. 2015; 60(3B):2373.

[32] Białobrzeska B., Kostencki P., Wear. 2015; 328329:149.

[33] Dudziński W., Konat Ł., Pękalski G., Modern constructional steels. In: DUDEK D., editor. Maintenance strategy of surface mining machines and facilities with high degree of technical degradation. Wroclaw: Publishing House of Wrocław University of Science and Technology; 2013. p. 341.

[34] Łętkowska B., Influence of heat treatment on structure and selected properties of B27 and 28MCB5 steels. Wroclaw: Publishing House of Wrocław University of Science and Technology; 2013.

[35] Dudziński W., Białobrzeska B., Konat Ł., Comparative analysis of structural and mechanical properties of selected low-alloy boron-containing abrasive-wear resistant steels. In: Świątkowski K, Dańko J, Dutkiewicz J., et al., editors. Polish metallurgy in the years 2011-2014. Cracow: Publishing House 'AKAPIT”; 2014. p. 871. 
[36] Pawlak K., Białobrzeska B., Konat Ł., Arch Civ Mech Eng. 2016; 16(4):913.

[37] Konat Ł., Pękalski G., Assessment of the condition of the constructional material. In: Dudek D., editor. Maintenance strategy of surface mining machines and facilities with high degree of technical degradation. Wroclaw: Publishing House of Wrocław University of Science and Technology; 2013. 329.

[38] Białobrzeska B., Konat Ł., Jasiński R., Metals-Basel. 2017; 7(1):26.

[39] Dudziński W., Konat Ł., Pękalski G., Arch Foundry Eng. 2008; 8(2):21.

[40] Dudziński W., Konat Ł., Pękalska L., Pękalski G., Mater Eng. 2006; 27(3):139.
[41] Frydman S., Konat Ł., Łętkowska B., Pękalski G., Arch Foundry Eng. 2008; 8(1):89.

[42] Wyrzykowski J.W., Pleszakow E., Sieniawski J., Deformation and cracking of metals. Warsaw: Publishing House "WNT"; 1999.

[43] Maciejny A., Brittleness of metals. Katowice: Publishing House "Śląsk"; 1973.

[44] Krauss G., Metall Mater Trans A. 2001; 32:861.

[45] Krauss G., ISIJ Int. 1995; 35(4):349.

Received 27-03-2021

Accepted 27-03-2021 